-the chair of mathematics and astronomy. In 1910 Sampson migrated still farther north, succeeding Sir Frank Dyson, on the latter's transference to Greenwich, as Astronom $э r$ Royal for Scotland and professor of astronomy in the University of Edinburgh.

Sampson's greatest work was his theory of the four great satellites of Jupiter. This immense undertaking, which involved the discussion of thousands of eclipses of the satellites and demanded qualities of perseverance and patience in addition to mathe. matical powers of the highest order, engrossed his attention for more than a quarter of a century. The observational material ho used fell into two categories : (1) old observations made visually, and (2) the photometric observations of the gradual disappearances of the satellites in eclipse, made at Harvard between 1878 and 1903. Although the general mathematical theory did not appear until 1921 (Mem. Roy. Astr. Soc., 63) the University of Durham undertook in 1910 the publication of the "Tables of the Four Great Satellites of Jupiter", and in the provious year Sampson's discussion of the photometric observations appeared in vol. 52 of the Harvard Annals. For these researches he was awarded in 1928 the Gold Medal of the Royal Astronomical Society.

Sampson's first research (1894) was on the "Rotation and Mechanical State of the Sun". At an early stage he became convinced that a satisfactory theory of the distribution of temperature in the interior of the sun was essential to his purpose. Ho discarded the principles of convective equilibrium and attempted a discussion of temperature conditions by means of simple hypotheses governing radiation and absorption-twenty years before the foundations of atomic physics were laid. In this work Sampson was a true pioneer. In 1900, he edited J. C. Adams's "Lectures on the Lunar Theory" and, later, the Adams manuscripts relating to the discovery of Neptune.

Sampson's most valuable contribution to astronomy during his directorship of the Royal Observatory in Edinburgh was his work on measuring the effective temperatures of the stars. During this period, too, he was greatly interested in the performance of clocks and he contributed many papers on this subject to the Royal Society of Edinburgh.

Sampson was elected to the Royal Society in 1903. From 1915 until 1917 he waspresident of the Royal Astronomical Society and for many years he acted as secretary of the Royal Society of Edinburgh. Ho held the honorary degrees of Sc.D. and LI.D. of Durham and Glasgow respectively, and in 1921 he was elected a corresponding member of the Bureau des Longitudes (Paris). He is survived by his wife, one son and four daughters.

IV. M. Silart.

\section{Prof. R. V. Wheeler}

Richard Versox Wheelen, director of the Safety in Mines Research Stations, professor of fuel technology in the University of Sheffield and editor of Fuel in Science and Practice, died at his home in Sheffield on October 28 at the age of fifty-six years. He graduated in the University of Manchester in
1903, where as an undergraduate he had already joined the band of research workers who laid the foundations of our present knowledge of flame and combustion, the famous Manchester school which will always be associated with the names of $H$. B. Dixon, W. A. Bone and R. V. Wheeler.

Wheeler became one of the leading authorities on safety in mines both in Great Britain and abroad, being awarded the Gold Medal of the Institution of Mining Engineers in 1937, and also one of the leading fuel technologists, receiving the Melchett Medal of the Institute of Fuel in 1938, but ho always remained at heart a research worker. Having little uso for the ad hoc and empirical type of research, he was fortunate in having the ability to convince those responsible for the organization and financing of the researches over which he had control of the importance and value of long-range and fundamental research. This ability was largely due to the clarity with which he explained complex problems to the non-scientific or nontechnical man. As a result he was enabled to build up teams of research workers who have carried out extensive investigations in each of the fields of work in which he was interested.

In dealing with some of the most important problems involved in the winning and utilization of coal, namely, dust explosions, spontaneous combustion, carbonization and industrial burning, Prof. Wheeler regarded a knowledge of the constitution of coal as being of prime importance. This was empha. sized in the "MIonograph on the Constitution of Coal" written by him and Dr. Mr. C. Stopes and published by the Department of Scientific and Industrial Research in 1918. In this publication, which greatlystimulated research in this field, they summarized critically the work already done, and surveyed the ground to be covered by future workers. Wheeler took a prominent part in the development of this work with the assistance of many collaborators, and the main results are to be found in a series of twenty-five papers in the Journal of the Chemical Society under the general heading of "Studies in the Composition of Coal". 'The application of these researches to the more technical problems was well brought out in a series of papers published in the technical press. In his work on the prevention of gaseous explosions he emphasized similarly the importance of a funda. mental knowledge of the mode of ignition and com. bustion of gaseous mixtures. The outstanding work in this direction was published in papers in the Journal of the Chemical Society dealing with the ignition of gases and with the uniform movement during the propagation of flame. The justification of his long-sighted policy is again shown by the important series of papers in the technical press showing how this knowledge could be applied.

Despite the wide range of the subjects of these researches, Prof. Wheeler always took keen interest in every piece of research under his direction, large or small, and was a continual source of suggestions and advice. He was an extremely hard worker, his enthusiasm for his work was infectious and he earned the esteem and respect of all those fortunate enough to work under him. 
No account of Prof. Wheeler would be complete without reference to the respect and affection felt for him by the mining community, men as well as masters, to whom his name was a household word. His staff at the Buxton Research Station of the Safety in Mines Research Board treasure the tributes paid to him by colliers visiting the Sunday 'demonstrations', referring to him, for example, as "the greatest friend of the miner since Sir Humplry Davy".

\section{W. PAYMan.}

\section{Vice-Admiral Sir Percy Douglas, K.C.B., C.M.G.}

Vice-Admiral Sir Percy Douglas, who died on November 4 at the age of sixty-three years, joined the surveying branch of the Royal Navy in 1898 and at once showed marked aptitude for this type of work. He possessed an alert brain and was more than a little interested in 'gadgets'; anything which could relieve the labours of the surveyor in the field was of particular interest to him, and being of an inventive turn of mind, he did a great deal to lighten their work and expedite production.

Whilst in command of H.M.S. Waterwitch on the China Station and in collaboration with the late Commander J. Sharpey-Schafer, Douglas introduced the Douglas-Schafer sounding gear, which was a great advance on former methods of sounding in comparatively shallow water ; later he was responsible for the Douglas protractor and, jointly with Prof. R. Appleyard, perfected the arcless sextant. During the War of 1914-18, Sir Percy was appointed to serve as hydrographic surveyor on the staff of the ViceAdmiral, Aegean, and at a later stage in the same capacity with the Flag Officer at Lover; between these two appointments he was the first director of the Naval Meteorological Service.

His knowledge of hydrography and geodesy was of the greatest assistance in the Dardanelles campaign, and also in the attacks on the Belgian coast, where indirect fire and bombardment was of such importance and where sound-ranging was developed to meet the need for the accurate bombardment of enemy gun positions.

After the War, Admiral Douglas interested himself in the development of echo sounding apparatus, and it was largely due to his initiative that the Admiralty echo sounding gear was perfected and brought into use. In addition to his official duties as hydrographer of the Navy, Sir Percy was, during his term of office, an ex officio member of the National Committee for Geodesy and Geophysics of the Royal Society, and served on the Council of the Royal Geographical Society.

Sir Percy became a member of the "Discovery" Committee in 1925 and his wide experience and knowledge were of immense benefit to this body. Shortly after his retirement he was appointed by the Board of Trade to be acting conservator of the Mersey and somewhat later became chairman of the Dover Harbour Board.

Sir Percy was a fellow of the Royal Astronomical
Society and of the Royal Geographical Society and a Younger Brother of Trinity House. At the time of his death he was serving as Commodore Superintendent of the Dockyard at Dover.

\section{J. A. FDGELL.}

\section{Dr. T. L. Prankerd}

IT is with deep regret that we record the tragic death in a street accident, on November 11, of Dr. T. L. Prankerd, for many years lecturer in botany in the University of Reading.

Theodora L. Prankerd was born in 1878 at Highgate, the daughter of Dr. O. R. Prankerd. She was educated at Brighton High School and the Royal Holloway College whence she graduated in science at the University of London. Later she was appointed to the staff of Bedford College (University of London) and then proceeded to carry out her early botanical researches at the University of Chicago. In 1917 she was appointed lecturer in botany in University College, Reading, where she remained until the College received its Royal Charter in 1926, and then she eontinued as lecturer in the University up to the time of her death. She was admitted fellow of the Linnean Society in 1919.

Dr. Prankerd's botanical researches were charac. terized by unlimited patience and exactitude. Her earlier work was morphological. In her first paper on the water violet, Hottonia, interest centres in pure anatomy and possible phylogeny; and this comes out more strongly in her next paper on a coal ball seed of which she gave a very careful description. Although her interest remained largely morphological, her other published papers aro concerned with the perception of the stimulus of gravity by organs, and reveal a great number of patient experiments. She ardently supported the theory of statolith perception, and although many consider that this conflicts with the hormone theory, she herself was trying to combine the two into a comprehensive theory of perception and transmission.

But it will not be as a research worker so much as a teacher and friend that Dr. Prankerd will be remembered. Hosts of students have passed through her hands. Nothing was too much trouble for her, and many a student will recall with gratitude the kindly help which she always offered; and this was not confined solely to study. She took a personal interest in her students.

Dr. Prankerd had a keen sense of justice and would stop at nothing in her efforts to make justice prevail whether for an ideal or an individual. For that reason she was sometimes judged harshly by others though never by anyone who was prepared to probe beneath that veneer of seeming forcefulness, for then they found a kindly and sympathetic woman. $\mathrm{He}$ or she who finally gained her friendship soon realized how intensely loyal she was. Sho was a woman, too, of great breadth of vision and high ideals. Thus, her life was not devoted solely to her plants. She was a great advocate of peace, and her efforts for the League of Nations Union were tireless. 